\title{
Pengaruh Kompensasi Dan Lingkungan Kerja Terhadap Kinerja Karyawan PT. Indo Tekhnoplus
}

\author{
N. Lilis Suryani \\ Dosen Fakultas Ekonomi Universitas Pamulang \\ Email : dosen00437@unpam.ac.id
}

\begin{abstract}
ABSTRAK
Penelitian ini bertujuan untuk mengetahui Kompensasi, Lingkungan Kerja dan Kinerja Karyawan serta pengaruh Kompensasi dan Lingkungan Kerja terhadap Kinerja Karyawan pada PT. Indo TekhnoPlus.

Metode penelitian yang digunakan asosiatif pendekatan kuantitatif. Dengan metode sampel jenuh diperoleh jumlah sampel sebanyak 60 responden. Pengumpulan data menggunakan angket kuesioner. Analisis data menggunakan SPSS 16.0 terdiri dari uji validitas, uji reliabilitas, analisis deskriptif, persamaan regresi linier berganda, analisis korelasi berganda, koefisien penentu, uji t dan uji F.

Berdasarkan hasil penelitian diperoleh persamaan regresi linier berganda $\mathrm{Y}=$ $9,919+0,236 \mathrm{X}_{1}+0,548 \mathrm{X}_{2}$, hal ini membuktikan bahwa kompensasi terhadap kinerja karyawan berpengaruh positif dan lingkungan kerja terhadap kinerja karyawan berpengaruh positif. Nilai korelasi berganda diperoleh angka R sebesar 0,745 . Berarti terdapat pengaruh yang kuat antara kompensasi, lingkungan kerja terhadap kinerja karyawan. Dilihat dari hasil koefisien penentu variabel independen yaitu kompensasi dan lingkungan kerja mampu menjelaskan bahwa variabel dependennya yaitu kinerja karyawan sebesar 53,9\% sedangkan sisanya 46,1\% dijelaskan oleh faktor-faktor lain. Uji signifikansi secara simultan $F_{\text {hitung }}>F_{\text {tabel }}$ atau 35,455 > 3,16 artinya $\mathrm{H}_{0}$ ditolak dan $\mathrm{H}_{\mathrm{a}}$ diterima atau kompensasi dan lingkungan kerja secara simultan berpengaruh signifikan terhadap kinerja karyawan PT. Indo TekhnoPlus.
\end{abstract}

\section{Kata Kunci ：Kompensasi, Lingkungan Kerja, Kinerja Karyawan}




\section{PENDAHULUAN}

\section{A. Latar Belakang Masalah}

Tercapainya suatu tujuan perusahaan bergantung pada kualitas sumber daya manusia yang dimiliki serta didukung oleh beberapa faktor produksi lainnya. Hal ini tidak lepas dari peran pemimpin dengan kepemimpinan yang partisipatif dan transparatif dalam bekerja sama dengan karyawan serta manajemen yang baik dalam perusahaan sehingga dapat mewujudkan tujuan organisasi atau perusahaan

Manajemen berasal dari bahasa inggris yaitu "manage" yang berarti, mengurus, mengelola, mengendalikan, mengusahakan, mempimpin Sedangkan pengertian manajemen secara etimologis adalah seni melaksanakan dan mengatur. Manajemen adalah suatu seni dalam ilmu dan proses pengorganisasian seperti perencanaan, pengorganisasian, pergerakan, dan pengendalian atau pengawasan.

Sumber daya manusia saat ini memiliki pengaruh besar pada sebuah perusahaan dimana sekarang berada pada perubahan lingkungan bisnis yang sulit untuk diprediksi dan tidak lagi berada pada lingkungan bisnis yang stabil. Sumber daya manusia adalah individu produktif yang bekerja sebagai penggerak suatu organisasi, baik itu didalam institusi maupun perusahaan yang memiliki fungsi sebagai asset sehingga harus dilatih dan dikembangkan kemampuannya.

Manajemen sumber daya manusia merupakan bagian sumber keorganisasian yang memfokuskan diri pada unsur sumber daya manusia. Tugas MSDM adalah mengelola unsur manusia secara baik agar diperoleh tenaga kerja yang puas akan pekerjaannya. Di dalam organisasi, manusia merupakan salah satu unsur terpenting didalam suatu organisasi. Tanpa peran manusia meskipun berbagai faktor yang dibutuhkan itu telah tersedia, organisasi tidak akan berjalan. Karena manusia merupakan penggerak dan penentu jalannya suatu organisasi. Oleh karena itu hendaknya organisasi memberikan arahan yang positif demi tercapainya tujuan organisasi.

Meskipun dalam praktiknya kinerja seseorang itu berbeda-beda antara satu dengan yang lainnya, namun kompensasi yang diberikan dengan bentuk uang atau barang adalah sarana untuk memenuhi kebutuhan karyawan. Kompensasi yang akan diterima oleh karyawan merupakan cermin dari apa yang telah diberikan karyawan kepada organisasi atau perusahaan. Dengan memberikan kompensasi yang dilaksanakan secara benar dapat memuaskan dan memotivasi karyawan guna mencapai tujuan organisasi atau perusahaan.

Kompensasi

merupakan komponen penting dalam hubunganya dengan karyawan. Kompensasi meliputi bentuk pembayaran tunai langsung, pembayaran tidak langsung dalam bentuk manfaat karyawan, dan insentif untuk memotivasi karyawan agar bekerja keras untuk mencapai produktvitas yang semakin tinggi. Dalam hal ini Yani (2012:139) mengemukakan sebagai berikut:

Kompensasi adalah bentuk pembayaran dalam bentuk manfaat dan insentif untuk memotivasi karyawan agar produktivitas kerja semakin meningkat.

Lingkungan kerja dalam suatu perusahaan atau organisasi perlu diperhatikan, hal ini disebabkan karena 
lingkungan kerja mempunyai pengaruh langsung terhadap karyawan. Lingkungan kerja yang kondusif memberikan rasa aman dan memungkinkan karyawan untuk dapat bekerja optimal. jika karyawan menyenangi lingkungan kerja dimana dia bekerja, maka karyawan tersebut akan betah ditempat kerjanya, melalukan aktivitasnya sehingga waktu kerja dipergunakan secara efektif. Sebaliknya jika lingkungan kerja tidak memadai akan dapat menurunkan kinerja karyawan. Mengenai hal ini beberapa ahli mendifinisikan lingkungan kerja antara lain sebagai berikut:

Menurut Danang Sunyoto (2012:43) mengemukakan lingkungan kerja adalah segala sesuatu yang ada disekitar para pekerja dan dapat mempengaruhi dirinya dalam menjalankan tugas-tugas yang dibebankan, misalnya kebersihan, music, penerangan dan lain-lain.

Sedangkan menurut Sedarmayati (2011:2) lingkungan kerja maksudnya adalah keseluruhan alat perkakas dan bahan yang dihadapi, lingkungan sekitarnya dimana seseorang bekerja, metode kerjanya, serta pengaturan kerjanya baik sebagai perseorangan maupun sebagai kelompok.

Setiap perusahaan selalu mengharapkan karyawannya mempunyai prestasi, karena dengan memiliki karyawan yang berprestasi akan memberikan sumbangan yang optimal bagi perusahaan. Salah satu faktor yang mempengaruhi tingkat keberhasilan suatu organisasi adalah kinerja karyawan. Kinerja berasal dari kata "job performance" yang berarti prestasi kerja atau prestasi sesungguhnya yang dicapai oleh seseorang. Kinerja karyawan adalah suatu tindakan yang dilakukan karyawan dalam melaksanakan pekerjaan yang diberikan perusahaan.

Dengan memberikan kompensasi, perusahaan menginginkan para karyawan mendapatkan kepuasan dalam bekerja yang merupakan pencapaian prestasi kerja yang akan memberikan karakteristik karyawan pada prestasi individualnya yang pada akhirnya akan terlihat pula peningkatan hasil kerja.

Dengan adanya kompensasi yang baik dan adil akan membuat kepuasan kerja pada karyawan yang akan memacu semangat dan kreativitas dalam bekerja sehingga dapat menunjukan prestasi kerja yang akhirnya akan meningkatkan produktivitas kerja yang bagus. Mengenai hal ini Hasibuan (2010:211) menjelaskan bahwa, "kepuasaan kerja adalah sikap emosional yang menyenangkan dan mencintai pekerjaannya. Sikap ini dicerminkan oleh moral kerja, kedisiplinan, dan prestasi kerja. Kepuasan kerja dinikmati dalam pekerjaan, luar pekerjaan, dan kombinasi antara keduanya".

karyawan akan lebih meningkatkan kinerjanya jika kepuasan kerjanya terpenuhi dan menjadikan tujuan perusahaan maupun kebutuhan karyawan juga terpenuhi. Begitu juga sebaliknya kepuasan kerja karyawan tidak terpenuhi maka tingkat kinerja karyawan akan menurun. Dengan memberikan kompensasi, perusahaan mengharapkan agar karyawan mencapai kepuasan kerja tersebut.

Suatu organisasi atau perusahaan untuk mencapai sebuah tujuannya bergantung pada kinerja karyawan. Maka dari itu pemberian kompensasi 
sangat amat penting untuk menunjang kepuasan kinerja karyawan agar produktivitas karyawan semakin baik. Begitu juga dengan memberikan kompensasi atas kinerja para karyawan akan memberikan timbal balik kontribusi untuk kelangsungan hidup pada organisasi atau perusahaan.

Pemberian kompensasi yang tidak adil dan baik, terkadang menimbulkan kecemburuan sosial antara karyawan yang satu dengan karyawan lainnya. Kondisi tersebut mengakibatkan menurunnya tingkat produktivitas dalam bekerja dan pekerjaan menjadi tidak selesai tepat waktu. Hal ini sangat merugikan bagi perusahaan karena dirasa tidak efektif, efisien, dan optimal maka akan mengakibatkan ketidakpuasan pelanggan atau vendor.

Oleh karena itu pemberian kompensasi yang adil dan benar sangat berpengaruh terhadap kinerja pegawai. Hal ini diatur oleh UU. NO. 13/2013 tentang ketenaga kerjaan bahwa, "Kesejahteraan pekerja atau buruh adalah suatu pemenuhan kebutuhan dan atau keperluan yang bersifat jasmaniah dan rohaniah, baik di dalam maupun di luar hubungan kerja, yang secara langsung atau tidak langsung dapat mempertinggi produktivitas kerja dalam lingkungan kerja yang aman dan sehat.

PT. Indo TekhnoPlus yang berlokasi di BSD Junction, Blok B N0. 28, Jl.Pahlawan Seribu, Serpong, Kota Tangerang Selatan, Banten 15320. merupakan perusahaan swasta yang bergerak dibidang distribusi dan perdagangan alat-alat kesehatan lingkungan, didirikan pada tahun 2009 di Tangerang. Bisnis utamanya adalah kegiatan manufaktur dan distributor, mempromosikan \& menjual barang di bidang kesehatan lingkungan.
Perusahaan ini adalah perusahaan yang baru mulai berkembang, sehingga belum diterapkan manajemen sumberdaya manusia secara professional. Sehingga masih terdapat ketidakadilan terhadap pemberian kompensasi terhadap karyawan dan lingkungan kerja yang kurang baik .

Untuk mengetahui lebih mendalam tentang permasalahan kompensasi dan lingkungan kerja yang kurang baik di PT. Indo Tekhnoplus, penulis tertarik untuk melakukan penelitian lebih lanjut mengenai pengaruh pemberian kompensasi dan lingkungan kerja yang baik bagi karyawan. Adapun judul yang diajukan adalah "Pengaruh kompensasi dan lingkungan kerja Terhadap Kinerja Karyawan PT. INDO TEKHNOPLUS".

\section{B. Perumusan Masalah}

Berdasarkan latar belakang penelitian diatas, maka dapat dirumuskan permasalahan terkait penelitian ini, diantaranya:

1. Apakah kompensasi memiliki pengaruh signifikan terhadap kinerja karyawan pada PT. Indo TeknoPus?

2. Apakah lingkungan kerja memiliki pengaruh signifikan terhadap kinerja karyawan pada PT.Indo TeknoPlus?

3. Apakah kompensasi dan lingkungan kerja secara bersamasama berpengaruh terhadap kinerja karyawan pada PT.Indo TeknoPlus?

\section{Tujuan Penelitian}

Sesuai dengan perumusan masalah sebelumnya, penelitian ini bertujuan untuk mengetahui: 
1. Pengaruh kompensasi terhadap kinerja karyawan pada PT. Indo TeknoPlus.

2. Pengaruh lingkungan kerja terhadap kinerja karyawan pada PT. Indo TeknoPlus.

3. Faktor kompensasi dan lingkungan kerja secara bersama-sama berpengaruh terhadap kinerja karyawan pada PT. Indo TeknoPlus.

\section{Manfaat Penelitian}

Penelitian ini diharapkan dapat bermanfaat secara teoritis dan praktis, diantaranya:

1. Teoritis

- Bagi Perusahaan diharapkan bisa memberikan informasi sebagai bahan masukan dan pertimbangan dalam upaya meningkatkan kinerja karyawan melalui peningkatan kompensasi dan lingkungan kerja.
- Bagi Fakultas Ekonomi Universitas Pamulang

Hasil penelitian ini dapat dijadikan sebagai bahan kepustakaan dan menambah referensi untuk mahasiswa dan adik-adik angkatan di Fakultas Ekonomi Universitas Pamulang.

2. Praktis

- Bagi Penulis

Dapat menambah pengetahuan dan wawasan mengenai kompensasi dan lingkungan kerja selain itu penelitian ini untuk mengembangkan dan menerapkan ilmu SDM yang sudah diperoleh di bamgku kuliah.

Bagi Pihak Lain

Hasil penelitian ini diharapkan dapat menjadi pengetahuan bagi pembaca dan dapat menjadi pertimbangan bagi perusahaan yang sedang menghadapi masalah yang sama

\section{E. Kerangka Berpikir}

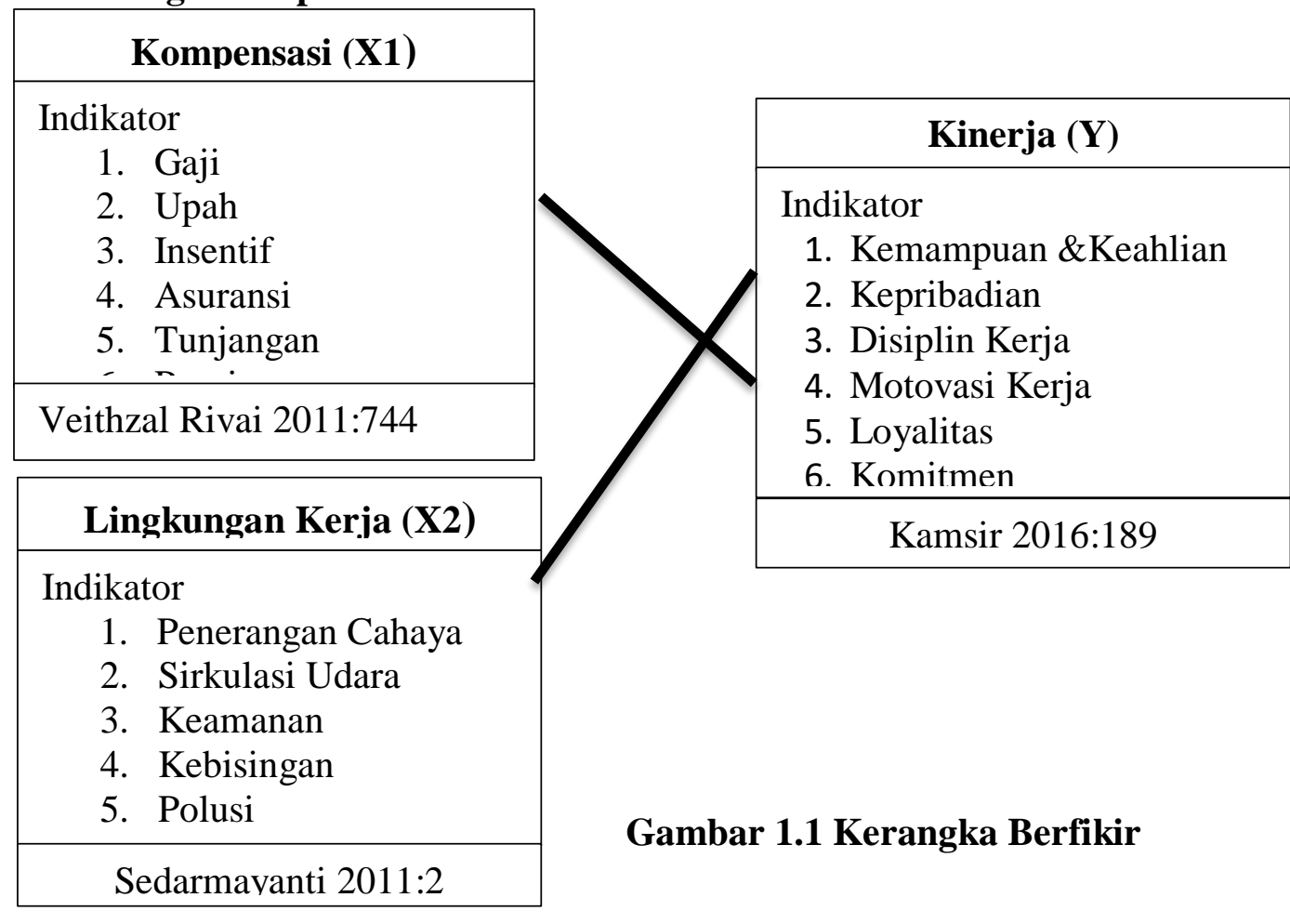




\section{F. Hipotesis}

Selanjutnya untuk hipotesis statistiknya adalah sebagai berikut:

Ho: Tidak terdapat pengaruh kompensasi dan lingkungan kerja terhadap kinerja karyawan pada PT.INDO TEKHNOPLUS. $\mathrm{Ha}$ : Terdapat pengaruh kompensasi dan lingkungan kerja terhadap kinerja karyawan pada PT. INDO TEKHNOPLUS

\section{TINJAUAN PUSTAKA}

\section{A. Kinerja}

Kinerja dalam suatu organisasi atau perusahaan merupakan salah satu unsur yang tidak dapat dipisahkan dalam menjalankan tugas organisasi. Kinerja sebagai hasil-hasil fungsi pekerjaan seseorang atau kelompok dalam suatu organisasi yang dipengaruhi oleh berbagai faktor untuk mencapai tujuan organisasi dalam waku tertentu.

Kinerja berasal dari kata job performance atau actual performance yang berarti prestasi kerja atau prestasi sesungguhnya yang dicapai oleh seseorang. Pengertian kinerja adalah hasil kerja secara kualitas dan kuantitas yang dicapai oleh seorang karyawan dalam melaksanakan fungsinya sesuai dengan tanggung jawab yang diberikan kepadanya.

Menurut Sedarmayanti
(2011:260) kinerja merupakan terjemahan dari performance yang berarti hasil kerja seorang pekerja, sebuah proses manajemen atau suatu organisasi secara keseluruhan, dimana hasil kerja tersebut harus dapat ditunjukan buktinya secara konkrit dan dapat diukur.

Moeheriono dalam Rosyida (2010:11) dalam bukunya menyimpulkan pengertian kinerja karyawan atau performance sebgai hasil kinerja yang dapat dicapai oleh seseorang atau kelompok orang dalam suatu organisasi baik secara kualitatif maupun secara kuantitatif, sesuai dengan kewenangan, tugas dan tanggung jawab masing-masing dalam upaya mencapai tujuan organisasi bersangkutan secara legal, tidak melanggar hukum dan sesuai dengan moral ataupun etika.

Sedangkan menurut Rivai dan Basri dalam kaswan (2012:187) kinerja adalah hasil atau tingkatan keberhasilan seseorang secara keseluruhan selama periode tertentu didalam melaksanakan tugas dibandingkan dengan berbagai kemungkinan, seperti standar hasil kerja, target atau sasaran, atau kinerja yang telah ditentukan terlebih dahulu dan telah disepakati bersama.

\section{B. KOMPENSASI}

Dalam meningkatkan efisiensi dan produktivitasnya salah satu cara yang ditempuh organisasi atau perusahaan untuk menciptakan kondisi tersebut adalah dengan memberikan kompensasi yang memuaskan. Dengan memberikan kompensasi perusahaan dapat meningkatkan prestasi kerja, motivasi, dan kepuasaan karyawan.

Kompensasi sangat penting bagi karyawan itu sendiri sebagai individu, karena besarnya kompensasi merupakan pencerminan atau ukuran nilai pekerjaan karyawan itu dan kepuasan kerja karyawan. Apabila kompensasi diberikan secara tepat dan benar para karyawan akan memperoleh kepuasan kerja dan akan termotivasi untuk mencapai tujuantujuan perusahaan. Akan tetapi bila 
kompensasi itu diberikan tidak memadai atau kurang tepat, prestasi kerja, motivasi, dan kepuasaan kerja akan menurun.

Menurut Sastrohadiwiryo (2013:125) kompensasi adalah imbalan jasa atau balas jasa yang diberikan oleh perusahaan kepada para tenaga kerja, karena para tenaga kerja tersebut telah memberikan sumbangan tenaga dan pikiran demi kemajuan perusahaan guna mencapai tujuan yang ditetapkan.

Selain itu menurut Ardana (2012:153) kompensasi adalah segala sesuatu yang diterima karyawan sebagai balas jasa atas kontribusinya kepada perusahaan atau organisasi.

Sedangkan menurut Hasibuan (2013:117) kompensasi adalah semua pendapatan yang berbentuk uang, barang langsung ataupun tidak langsung yang diterima oleh karyawan sebagai imbalan atas yang diberikan kepada perusahaan.

Jadi dapat disimpulkan dari beberapa pengertian para ahli di atas bahwa kompensasi merupakan hasil yang diperoleh sebagai bentuk imbalan atau balas jasa yang diberikan perusahaan kepada para karyawan atas kontirbusinya terhadap perusahaan atau organisasi.

\section{LINGKUNGAN KERJA}

Lingkungan kerja mempunyai pengaruh yang cukup besar terhadap jalannya operasi perusahaan. Sehingga perusahaan perlu memberikan perhatian lebih terhadap lingkungan perusahaan tersebut, sehingga karyawan dapat bekerja secara optimal dan dapat mencapai tujuan perusahaan seperti yang diinginkan.

$$
\text { Lingkungan kerja adalah }
$$
kehidupan sosial, psikologi, dan fisik dalam perusahaan yang berpengaruh terhadap pekerja dalam melaksanakan tugasnya. Kehidupan manusia tidak terlepas dari berbagai keadaan lingkungan sekitarnya, antara manusia dan lingkungan terdapat hubungan yang sangat erat. Kondisi lingkungan kerja dikatakan baik atau sesuai apabila manusia dapat melaksanakan kegiatan secara optimal, sehat, aman, dan nyaman.

Menurut Nitisemito (dalam Nuraini 2013:97) Lingkungan kerja adalah segala sesuatu yang ada disekitar karyawan dan dapat mempengaruhi dalam menjalankan tugas yang diembankan kepadanya misalnya dengan adanya air conditioner (AC), penerangan yang memadai dan sebagainya.

Sedangkan menurut Sedarmayanti (2011:2) Lingkungan kerja maksudnya adalah keseluruhan alat perkakas dan bahan yang dihadapi, lingkungan sekitarnya dimana seseorang bekerja, metode kerjanya, serta pngaturan kerjanya yang baik sebagai perseorangan maupun sebagai kelompok.

Dapat disimpulkan dari beberapa pengertian-penegertian para ahli diatas bahwa lingkungan kerja merupakan segala sesuatu yang ada disekitar karyawan saat bekerja, baik yang bersifat fisik maupun non fisik, baik langsung ataupun tidak langsung, yang dapat mempengaruhi kinerja karyawan saat melaksanakan pekerjaannya.

\section{METODOLOGI PENELITIAN}

\section{A. Ruang Lingkup}

1. Tempat Penelitian

Dalam menyusun penelitian ini penulis melakukan penelitian pada PT. Indo TekhnoPlus yang berlokasi di 
BSD Junction, Blok B N0. 28, J1.Pahlawan Seribu, Serpong, Kota Tangerang Selatan, Banten 15320. Dengan jumlah karyawan 60.

2. Waktu Penelitian

Waktu penelitian ini dilaksanakan sejak bulan Februari sampai dengan Mei 2018.

3. Sifat Penelitian

Jenis atau sifat penelitian yang digunakan dalam penelitian ini adalah penelitian asosiatif kausal dengan pendekatan kuantitatif. Penelitian asosiatif merupakan penelitian yang betujuan untuk mengetahui hubungan antara dua variabel atau lebih, sedangkan pendekatan kuantitatif digunakan karena data dalam penelitian ini dinyatakan dalam angka-angka, bila serangkaian observasi atau pengukuran dapat dinyatakan dalam angka-angka hasil observasi atau pengukuran demikian itu dinamakan data kuantitatif.

Berdasarkan beberapa pengertian tersebut, maka jenis penelitian yang digunakan dalam penelitian ini adalah penelitian kausal atau hubungan yang bersifat sebabakibat. Hubungan yang bersifat sebabakibat (Sugiyono, 2013:30). Variabel independen dalam bahasa indonesia sering disebut variabel bebas. Variabel bebas adalah merupakan variabel yang mempengaruhi atau yang menjadi akibat, karena adanya variabel bebas. Penelitian ini menghubungkan kompensasi dan lingkungan kerja sebagai variabel bebas dan kinerja karyawan sebagai variabel terikat.

\section{A. Populasi Dan Sampel}

1. Populasi Penelitian

Populasi merupakan subyek penelitian. Populasi adalah wilayah generaisasi yang terdiri atas obyek atau subyek yang mempunyai kualitas dan karakteristik tertentu yang ditetapkan oleh peneliti untuk dipelajari dan kemudian ditarik kesimpulannya Sugiyono (2013:117). Jadi, populasi bukan hanya orang tetapi juga obyek dan benda-benda alam yang lain. Populasi bukan juga bukan sekedar jumlah yang ada pada obyek atau subyek yang dipelajari, tetapi meliputi seluruh karakteristikatau sifat yang dimiliki oleh subyek atau obyek itu. Kriteria sampel yang ditetapkan oleh penulis dalam pemilihan sampel adalah seluruh karyawan yang bekerja di PT. Indo TekhnoPlus dengan jumlah karyawan sebanyak 60 .

2. Sampel

Sampel adalah bagian dari jumlah dan karakteristik yang dimiliki oleh populasi tersebut Sugiyono (2014:81). Bila populasi besar dan peneliti tidak mungkin mempelajari semua yang ada pada populasi, misalnya karna keterbatasan data, tenaga dan waktu, maka penelti dapat menggunakan sampel yang diambil dari populasi itu. Jadi sampel sama dengan populasi sebanyak 60 responden. Keseluruhan responden tersebut yang nantinya akan mendapatkan kuisioner dengan beberapa pertanyaan, dengan harapan kuisioner tersebut dapat diisi dengan sebenar-benarnya, sehingga hasilnya akan akurat.

\section{ANALISIS DAN PEMBAHASAN}

\section{Karakteristik Responden}

Objek dalam penelitian ini adalah seluruh karyawan PT. Indo TekhnoPlus yang berlokasi di BSD Junction, Blok B- 28, Jl. Pahlawan Seribu, BSD City, Serpong, Tangerang Selatan, 15322. 
Jumlah responden yaitu 60 orang. Berikut ini adalah hasil penyajian mengenai karakteristik responden.

\section{Tabel 4.1}

Karakteristik Responden

Berdasarkan Jenis Kelamin

\begin{tabular}{|c|c|c|}
\hline $\begin{array}{c}\text { Jenis } \\
\text { Kelami } \\
\text { n }\end{array}$ & $\begin{array}{c}\text { Jumlah } \\
\text { Responde } \\
\text { n }\end{array}$ & $\begin{array}{c}\text { Persentas } \\
\text { e }\end{array}$ \\
\hline pria & 26 & $43,3 \%$ \\
\hline wanita & 34 & $56,7 \%$ \\
\hline Total & 60 & $100 \%$ \\
\hline
\end{tabular}

(sumber : Data diolah 2018)

Berdasarkan Tabel 4.1 diatas dapat dilihat bahwa responden berjenis kelamin pria berjumlah 26 responden $(43,3 \%)$, dan berjenis kelamin wanita berjumlah 34 responden $(56,7 \%)$ dari keseluruhan responden.

\section{Tabel 4.2}

Karakteristik Responden Berdasarkan Usia

\begin{tabular}{|c|c|c|}
\hline Usia & $\begin{array}{c}\text { Jumlah } \\
\text { Responden }\end{array}$ & Persentase \\
\hline$<20$ & 2 & $3,3 \%$ \\
\hline $21-30$ & 17 & $28,3 \%$ \\
\hline $31-40$ & 28 & $46,7 \%$ \\
\hline$>40$ & 13 & $21,7 \%$ \\
\hline Total & 60 & $100 \%$ \\
\hline
\end{tabular}

(sumber : Data diolah 2018)

Berdasarkan Tabel 4.2 dapat dilihat usia $<20$ tahun sebanyak 2 responden $(3,3 \%), \quad 21-30$ tahun sebanyak17responden $(28,3 \%), 31-40$ sebanyak 28 responden $(46,7 \%),>40$ sebanyak 13 responden $(21,7 \%)$.

\section{Tabel 4.3}

Kelompok Responden Berdasarkan Pendidikan Terakhir

\begin{tabular}{|c|c|c|}
\hline Pendidikan & $\begin{array}{c}\text { Jumlah } \\
\text { Responden }\end{array}$ & Persentase \\
\hline SLTA & 18 & $30 \%$ \\
\hline Diploma3 & 12 & $20 \%$ \\
\hline Strata1 & 20 & $33,3 \%$ \\
\hline Strata2 & 10 & $16,7 \%$ \\
\hline Total & 60 & $100 \%$ \\
\hline
\end{tabular}

(sumber : Data diolah 2018)
Berdasarkan Tabel 4.3 dapat dilihat pendidikan SLTA sebanyak 18 responden (30\%), pendidikan D3 sebanyak 12 responden (20\%), pendidikan S1 sebanyak 20 responden $(33,3 \%)$, pendidikan S2 sebanyak 10responden $(16,7 \%)$.

Tabel 4.4

Kelompok Responden Berdasarkan Masa Kerja

\begin{tabular}{|c|c|c|}
\hline $\begin{array}{c}\text { Masa } \\
\text { Kerja }\end{array}$ & $\begin{array}{c}\text { Jumlah } \\
\text { Responden }\end{array}$ & Persentase \\
\hline 1-3 tahun & 6 & $10 \%$ \\
\hline $4-5$ tahun & 24 & $40 \%$ \\
\hline $\begin{array}{c}\text { 6-10 } \\
\text { tahun }\end{array}$ & 30 & $50 \%$ \\
\hline Total & 60 & $100 \%$ \\
\hline
\end{tabular}

( sumber : data diolah 2018)

Dari tabel 4.4 responden berdasarkan masa kerja dapat disimpulkan bahwa responden atau karyawan yan masa kerja 1-3 tahun ada 6 responden atau (10\%), dan karyawan masa kerja 4-5 tahun ada 24 responden atau $(40 \%)$ dan karyawan masa kerjanya 6-10 tahun ada 30 responden atau (50\%).

\section{A. Uji Validitas dan Uji Reabilitas}

1. Uji Validitas

Uji Validitas daftar pertanyaan untuk mengukur sah atau valid tidaknya suatu kuisioner. Suatu kuisioner dikatakan valid jika pertanyaan pada kuisioner mampu menganggap sesuatu yang diukur oleh kuisiner tersebut adalah dengan menggunakan metode corrected item-total correlation yaitu dilakukan dengan cara mengkorelasikan masing-masing skor item dengan skor total dan melakukan korelasi terhadap nilai koefisien korelasi yang over estimate.

Dalam penentuan layak atau tidaknya item yang akan digunakan biasanya dilakukan uji signifikan. 
Oleh karena itu dengan ketentuanketentuan penilaian butir yang mempunyai korelasi positif dengan kriterium (skor total) serta korelasinya tinggi, menunjukan bahwa butir tersebut mempunyai validitas yang tinggi pula.

Tabel 4.5 Validitas indikator Kompensasi

\begin{tabular}{|c|c|c|c|c|}
\hline $\begin{array}{c}\text { N } \\
\text { o. }\end{array}$ & $\begin{array}{c}\text { Indika } \\
\text { tor }\end{array}$ & $\begin{array}{c}\text { Rhitu } \\
\text { g }\end{array}$ & $\begin{array}{c}\text { Rtab } \\
\text { el } \\
\alpha 0,0 \\
5\end{array}$ & $\begin{array}{c}\text { Keteran } \\
\text { gan }\end{array}$ \\
\hline 1 & KP1 & 0,860 & $\begin{array}{c}0,25 \\
4\end{array}$ & VALID \\
\hline 2 & KP2 & 0,842 & $\begin{array}{c}0,25 \\
4\end{array}$ & VALID \\
\hline 3 & KP3 & 0,843 & $\begin{array}{c}0,25 \\
4\end{array}$ & VALID \\
\hline 4 & KP4 & 0,843 & $\begin{array}{c}0,25 \\
4\end{array}$ & VALID \\
\hline 5 & KP5 & 0,785 & $\begin{array}{c}0,25 \\
4\end{array}$ & VALID \\
\hline 6 & KP6 & 0,808 & $\begin{array}{c}0,25 \\
4\end{array}$ & VALID \\
\hline 7 & KP7 & 0,338 & $\begin{array}{c}0,25 \\
4\end{array}$ & VALID \\
\hline 8 & KP8 & 0,589 & $\begin{array}{c}0,25 \\
4\end{array}$ & VALID \\
\hline 9 & KP9 & 0,713 & $\begin{array}{c}0,25 \\
4\end{array}$ & VALID \\
\hline 10 & KP10 & 0,441 & $\begin{array}{c}0,25 \\
4\end{array}$ & VALID \\
\hline
\end{tabular}

Sumber: Hasil Pengolahan Data SPSS 16.0, 2018

Berdasarkan tabel diatas, dapat dilihat bahwa 10 butir item pertanyaan untuk variabel kompensasi dinyatakan seluruh item tersebut adalah valid. Dimana $\mathrm{n}$ adalah jumlah responden dengan $\alpha=0,05$ dan dalam penelitian ini, nilai rtabel didapat adalah 0,254. Karena nilai corrected item total correlation lebih besar dibanding 0,254 dari item kuisioner yang valid dapat dijadikan acuan untuk penelitian selanjutnya dan hasilnya dapat dilihat pada tabel 4.5 diatas.
Tabel 4.6 Validitas indikator Lingkungan Kerja

\begin{tabular}{|c|c|c|c|c|}
\hline No. & Indikator & Rhitung & $\begin{array}{c}\text { Rtabel } \\
\alpha 0,05\end{array}$ & Keterangan \\
\hline 1 & LK1 & 0,691 & 0,254 & VALID \\
\hline 2 & LK2 & 0,709 & 0,254 & VALID \\
\hline 3 & LK3 & 0,735 & 0,254 & VALID \\
\hline 4 & LK4 & 0,720 & 0,254 & VALID \\
\hline 5 & LK5 & 0,605 & 0,254 & VALID \\
\hline 6 & LK6 & 0,775 & 0,254 & VALID \\
\hline 7 & LK7 & 0,746 & 0,254 & VALID \\
\hline 8 & LK8 & 0,749 & 0,254 & VALID \\
\hline 9 & LK9 & 0,706 & 0,254 & VALID \\
\hline 10 & LK10 & 0,470 & 0,254 & VALID \\
\hline
\end{tabular}

Sumber: Hasil Pengolahan Data SPSS 16.0, 2018

Berdasarkan tabel diatas, dapat dilihat bahwa 10 butir item pertanyaan untuk variabel lingkungan kerja dinyatakan seluruh item tersebut adalah valid. Dimana $n$ adalah jumlah responden dengan $\alpha=0,05$ dan dalam penelitian ini, nilai rtabel didapat adalah 0,254. Karena nilai corrected item total correlation lebih besar dibanding 0,254 dari item kuisioner yang valid dapat dijadikan acuan untuk penelitian selanjutnya dan hasilnya dapat dilihat pada Tabel 4.6 diatas.

Tabel 4.7 Validitas Indikator Kinerja Karyawan

\begin{tabular}{|c|c|c|c|c|}
\hline $\begin{array}{c}\mathrm{N} \\
\text { o. }\end{array}$ & $\begin{array}{c}\text { Indik } \\
\text { ator }\end{array}$ & $\begin{array}{c}\text { Rhitu } \\
\text { ng }\end{array}$ & $\begin{array}{c}\text { Rta } \\
\text { bel } \\
\alpha 0,0 \\
5\end{array}$ & $\begin{array}{c}\text { Keteran } \\
\text { gan }\end{array}$ \\
\hline 1 & KK1 & $\begin{array}{c}0,83 \\
7\end{array}$ & $\begin{array}{c}0,25 \\
4\end{array}$ & VALID \\
\hline 2 & KK2 & $\begin{array}{c}0,83 \\
9\end{array}$ & $\begin{array}{c}0,25 \\
4\end{array}$ & VALID \\
\hline
\end{tabular}




\section{JENIUS}

\begin{tabular}{|c|c|c|c|l|}
\hline 3 & KK3 & 0,83 & 0,25 & VALID \\
& & 2 & 4 & \\
\hline 4 & KK4 & 0,80 & 0,25 & VALID \\
& & 3 & 4 & \\
\hline 5 & KK5 & 0,82 & 0,25 & VALID \\
& & 0 & 4 & \\
\hline 6 & KK6 & 0,75 & 0,25 & VALID \\
& & 6 & 4 & \\
\hline 7 & KK7 & 0,80 & 0,25 & VALID \\
& & 6 & 4 & \\
\hline 8 & KK8 & 0,78 & 0,25 & VALID \\
& & 2 & 4 & \\
\hline 9 & KK9 & 0,84 & 0,25 & VALID \\
& & 0 & 4 & \\
\hline 10 & KK10 & 0,72 & 0,25 & VALID \\
& & 7 & 4 & \\
\hline
\end{tabular}

Sumber: Hasil Pengolahan Data SPSS 16.0, 2018

Berdasarkan tabel diatas, dapat dilihat bahwa 10 butir item pertanyaan untuk variabel kinerja karyawan dinyatakan seluruh item tersebut adalah valid. Dimana $n$ adalah jumlah responden dengan $\alpha=0,05$ dan dalam penelitian ini, nilai rtabel didapat adalah 0,254. Karena nilai corrected item total correlation lebih besar dibanding 0,254 dari item kuesioner yang valid dapat dijadikan acuan untuk penelitian selanjutnya dan hasilnya dapat dilihat pada tabel 4.7 diatas.

2. Uji Reliabilitas

Uji Reliabilitas bertujuan untuk mengetahui besarnya indeks kepercayaan instrumen dari variabel kompensasi, lingkungan kerja dan kinerja karyawan setelah dilakukan uji validitas dan diperoleh butir pertanyaan yang valid, selanjutnya dilakukan uji reliabilitas dengan menggunakan rumus cronbach alpha. Keputusan untuk mengetahui bahwa instrumen adalah reliabel jika nilai $r$ alpha $>0,6$ dari analisis dengan mengunakan program SPSS 16.0 diperoleh uji reliabilitas seperti pada tabel dibawah ini:

Tabel 4.8 Uji Reliabilitas Cronbach Alpha

\begin{tabular}{|c|c|c|}
\hline Variabel & $\begin{array}{c}\mathrm{r} \\
\text { alpha }\end{array}$ & Keterangan \\
\hline Kompensasi & 0,895 & Reliabel \\
\hline $\begin{array}{c}\text { Lingkungan } \\
\text { Kerja }\end{array}$ & 0,873 & Reliabel \\
\hline $\begin{array}{c}\text { Kinerja } \\
\text { Karyawan }\end{array}$ & 0,939 & Reliabel \\
\hline
\end{tabular}

Sumber: Hasil Pengolahan Data Kuesioner, 2018

Dari hasil uji reliabilitas instrumen menunjukan bahwa ketiga variabel gaya kepemimpinan, disiplin kerja, kinerja karyawan adalah reliabel karena nilai $r$ alpha $>0,6$.

\section{Analisis Deskriptif}

a. Analisis Deskriptif kompensasi

Berdasarkan hasil penelitian yang diperoleh bahwa kompensasi di PT. Indo TekhnoPlus berada pada kategori baik. Hal ini dibuktikan dengan jumlah hasil kuisioner $\mathrm{SS}+\mathrm{S}=18,3 \%+60,7 \%=79 \%$, seperti pada perhitungan dibawah :

Presentase jawaban diperoleh dari jumlah jawaban dari setiap masing-masing skala dibagi dengan total keseluruhan jawaban $110+$ $364+97+11+18=600$ atau:

$\mathrm{SS}=110 \times 100 \%=18,3 \%$

60

$S=364 \times 100 \%=60,7 \%$

60

$\mathrm{R}=\frac{97}{60} \times 100 \%=16.2 \%$

$\mathrm{TS}=11 \times 100 \%=1,8 \%$ 60

$\mathrm{STS}=18 \times 100 \%=3 \%$ 60 
Dari tabel hasil responden variabel kompensasi pada PT. Indo TekhnoPlus, dapat dilihat rincian hasil pernyataan responden sebagai berikut: yang menjawab "Sangat Setuju" sebanyak 110 responden atau 18,3\%, yang menjawab "Setuju" sebanyak 364 responden atau $60,7 \%$, yang menjawab "Ragu" sebanyak 97 responden atau 16,2\%, yang menjawab "Tidak Setuju" sebanyak 11 responden atau $1,8 \%$, dan yang menjawab "Sangat Tidak Setuju" sebanyak 18 responden atau $3 \%$. b. Analisis
Deskriptif

\section{Lingkungan Kerja}

Berdasarkan hasil penelitian yang diperoleh bahwa lingkungan kerja di PT. Indo TekhnoPlus berada pada kategori baik. Hali ini dibuktikan dengan jumlah hasil kuisioner $\mathrm{SS}+\mathrm{S}=$ $30,5 \%+57,7 \%=88,2 \%$ seperti pada perhitungan dibawah :

Presentase jawaban diperoleh dari jumlah jawaban dari setiap masingmasing skala dibagi dengan total keseluruhan jawaban $183+346+47+12+12=600$, atau :

$$
\begin{aligned}
& \mathrm{SS}=183 \times 100 \%=30,5 \% \\
& \frac{60}{6}=\frac{346}{60} \times 100 \%=57 \% \\
& \mathrm{R}=\frac{47}{60} \times 100 \%=7,8 \% \\
& \mathrm{TS}=\frac{12}{60} \times 100 \%=2 \% \\
& \mathrm{STS}=\frac{12}{60} \times 100 \%=2 \%
\end{aligned}
$$

Dari tabel hasil responden variabel kompensasi pada PT. Indo TekhnoPlus, dapat dilihat rincian hasil pernyataan responden sebagai berikut: yang menjawab "Sangat Setuju" sebanyak 183 responden atau 30,5\%, yang menjawab "Setuju" sebanyak 346 responden atau 57\%, yang menjawab "Ragu" sebanyak47 responden atau $7,8 \%$, yang menjawab "Tidak Setuju" sebanyak 12 responden atau 2\%, dan yang menjawab "Sangat Tidak Setuju" sebanyak 12 responden atau $2 \%$.

c. Analisis Deskriptif Kinerja Karyawan

Berdasarkan hasil penelitian yang diperoleh bahwa lingkungan kerja di PT. Indo TekhnoPlus berada pada kategori baik. Hali ini dibuktikan dengan jumlah hasil kuisioner $\mathrm{SS}+\mathrm{S}=27,3 \%+66,5 \%=$ $93,8 \%$.seperti pada perhitungan dibawah :

Presentase jawaban diperoleh dari jumlah jawaban dari setiap masingmasing skala dibagi dengan total keseluruhan jawaban $183+346+47+12+12=600$, atau :

$$
\begin{aligned}
& \mathrm{SS}=\frac{164}{60} \times 100 \%=27,3 \% \\
& \mathrm{~S}=\frac{399}{\frac{60}{60}} \times 100 \%=66,5 \% \\
& \mathrm{R}=\frac{26}{60} \times 100 \%=4,3 \% \\
& \mathrm{TS}=\frac{1}{60} \times 100 \%=0,2 \% \\
& \mathrm{STS}=\frac{10}{60} \times 100 \%=1,7 \%
\end{aligned}
$$

Dari tabel hasil responden variabel kompensasi pada PT. Indo TekhnoPlus, dapat dilihat rincian hasil pernyataan responden sebagai berikut: yang menjawab "Sangat Setuju" sebanyak 164responden atau 27,3\%, yang menjawab "Setuju" sebanyak 399 responden atau $66,5 \%$, yang menjawab "Ragu" sebanyak 26 responden atau $4,3 \%$, yang menjawab "Tidak Setuju" sebanyak 1 responden atau $0,2 \%$, dan yang menjawab "Sangat Tidak Setuju" sebanyak 10 responden atau $1,7 \%$. 


\section{PEMBAHASAN}

1. Persamaan Regresi Linear Berganda

Analisis regresi linear berganda digunakan dalam penelitian ini dengan tujuan untuk membuktikan hipotesis mengenai adanya pengaruh variabel Kompensasi $\left(\mathrm{X}_{1}\right)$ dan Lingkungan Kerja $\left(\mathrm{X}_{2}\right)$ secara parsial maupun bersama-sama terhadap Kinerja Karyawan (Y). Perhitungan statistik dalam analisis regresi linear berganda yang digunakan dalam penelitian ini adalah dengan menggunakan program SPSS 16.0. Hasilnya dapat dilihat pada tabel berikut:

Tabel 4.9 Hasil Olahan Data Regresi Berganda Coefficients $^{a}$

\begin{tabular}{|c|c|c|c|c|c|}
\hline \multirow[b]{2}{*}{ Model } & \multicolumn{2}{|c|}{$\begin{array}{c}\text { Unstandar } \\
\text { dized } \\
\text { Coefficient } \\
s \\
\end{array}$} & $\begin{array}{c}\begin{array}{c}\text { Standard } \\
\text { ized } \\
\text { Coefficie } \\
\text { nts }\end{array} \\
\end{array}$ & \multirow[b]{2}{*}{$\mathrm{T}$} & \\
\hline & B & $\begin{array}{c}\text { Std. } \\
\text { Erro } \\
r \\
\end{array}$ & Beta & & $\begin{array}{l}\text { Si } \\
\text { g. }\end{array}$ \\
\hline $1 \begin{array}{l}\text { (Consta } \\
\mathrm{nt})\end{array}$ & 9.919 & 3.807 & & $\begin{array}{r}2.6 \\
05 \\
\end{array}$ & $\begin{array}{r}.01 \\
2 \\
\end{array}$ \\
\hline $\begin{array}{l}\text { Kompen } \\
\text { sasi } \\
\text { (X1) } \\
\text { Lingkun } \\
\text { gan } \\
\text { Kerja } \\
\text { (X2) }\end{array}$ & .236 & .117 & .549 & $\begin{array}{r}2.1 \\
98\end{array}$ & $\begin{array}{r}.03 \\
2\end{array}$ \\
\hline
\end{tabular}

a. Dependent Variable: Kinerja Karyawan (Y)

Berdasarkan tabel 4.9 yakni hasil olahan data regresi dengan menggunakan program SPSS 16.0 maka persamaan regresinya yaitu:

$\mathrm{Y}=\mathbf{9 , 9 1 9}+\mathbf{0 , 2 3 6} \mathrm{X}_{1}+\mathbf{0 , 5 4 8 X _ { 2 }}$

Dimana :

$\mathrm{X}_{1}$ : Kompensasi

$\mathrm{X}_{2}$ : Lingkungan Kerja

$\mathrm{Y}$ : Kinerja Karyawan
Dari persamaan regresi diatas maka dapat diinterprestasikan beberapa hal, antara lain:

a. Nilai konstanta persamaan diatas adalah sebesar 9,919. Angka tersebut menunjukan tingkat kinerja karyawan yang diperoleh oleh perusahaan bila variabel kompensasi dan lingkungan kerja diabaikan. Artinya ketika dua variabel diabaikan maka variabel kinerja karyawan bernilai positif.

b. Variabel kompensasi memiliki nilai koefisien regresi yang positif yaitu sebesar 0,236. Nilai koefisien positif menunjukan bahwa kompensasi terhadap kinerja karyawan berpengaruh positif. Hal ini menggambarkan bahwa nilai kinerja karyawan akan mengalami peningkatan sebesar koefisien pengali dari kompensasi, dengan asumsi variable independent konstan.

c. Variabel lingkungan kerja memiliki nilai koefisien regresi yang positif yaitu sebesar 0,548. Nilai koefisen positif menunjukan bahwa lingkungan kerja terhadap kinerja karywan berpengaruh positif. Hal ini menggambarkan bahwa nilai kinerja karyawan akan mengalami peningkatan sebesar koefisien pengali dari lingkungan kerja, dengan asumsi variabel independent lain dianggap konstan.

2. Analisis Korelasi Berganda Analisis yang digunakan untuk mengetahui tingkat keeratan atau kekuatan hubungan antara variabelvariabel (Kompensasi), (Lingkungan Kerja), dan (Kinerja Karyawan). Korelasi yang digunakan adalah korelasi berganda, hasil korelasi dengan menggunakan SPSS 16.0 adalah sebagai berikut : 
Tabel 4.10 Hasil Olahan Data Regresi Berganda

Berdasarkan tabel 4.10 hasil analisis korelasi berganda diperoleh angka $\mathrm{R}$ sebesar 0,745 . Hal ini menunjukan bahwa kompensasi dan lingkungan kerja memiliki hubungan yang signifikan dengan kinerja karawan. Karena termasuk kriteria pada interval $0,50-0,75$ hubungan korelasi kuat.

\section{Koefisien Penentu}

Koefisien penentu (KP) pada intinya mengukur seberapa jauh kemampuan suatu model dalam menerangkan variabel dependen. $\mathrm{R}^{2}$ memiliki kelemahan tersebut maka digunakan koefisien determinasi yang telah disesuaikan yaitu adjusted $R$ square ( $\mathrm{R}^{2} \mathrm{adj}$ ).

\section{Tabel 4.11 Hasil Olahan Data Koefisien Penentu}

Model Summary

\begin{tabular}{|c|c|c|c|c|c|c|c|c|c|}
\hline \multirow[b]{2}{*}{$\begin{array}{l}\text { Mo } \\
\text { del }\end{array}$} & \multirow[b]{2}{*}{$R$} & \multirow[b]{2}{*}{$\begin{array}{c}\mathrm{R} \\
\text { Squ } \\
\text { are }\end{array}$} & \multirow[b]{2}{*}{$\mid \begin{array}{c}\text { Adjus } \\
\text { ted R } \\
\text { Squa } \\
\text { re }\end{array}$} & \multirow[b]{2}{*}{$\begin{array}{l}\text { Std. } \\
\text { Error } \\
\text { of the } \\
\text { Estim } \\
\text { ate }\end{array}$} & \multicolumn{5}{|c|}{ Change Statistics } \\
\hline & & & & & $\begin{array}{c}\text { R } \\
\text { Squ } \\
\text { are } \\
\text { Cha } \\
\text { nge }\end{array}$ & $\begin{array}{c}\mathrm{F} \\
\text { Cha } \\
\text { nge }\end{array}$ & $\begin{array}{c}\mathrm{df} \\
1\end{array}$ & $\begin{array}{l}d f \\
2\end{array}$ & $\begin{array}{c}\text { Sig. } \\
F \\
\text { Cha } \\
\text { nge }\end{array}$ \\
\hline 1 & $\begin{array}{r}.74 \\
5^{\mathrm{a}}\end{array}$ & .554 & .539 & 3.635 & .554 & $\begin{array}{r}35.4 \\
55 \\
\end{array}$ & 2 & $\begin{array}{l}5 \\
7\end{array}$ & .000 \\
\hline
\end{tabular}

a. Predictors: (Constant), Disiplin

Kerja, Gaya Kepemimpinan

Sumber : Hasil Output SPSS 16.0

Penelitian ini mengunakan koefisien penentu yang telah disesuaikan atay biasa disebut adjusted $R$ square ( $\left.\mathrm{R}^{2} \mathrm{adj}\right)$. Dari hasil analisis tabel 4.11 dapat diketahui bahwa nilai adjusted $R$ square pada analisis regresi tersebut sebesar 0,539 yang berarti bahwa variabel independen yaitu kompensasi dan lingkungan kerja mampu menjelaskan bahwa variabel dependennya yaitu kinerja karyawan sebesar $53,9 \%$ sedangkan sisanya $46,1 \%$ dijelaskan oleh faktor-faktor lain yang tidak dicantumkan dalam penelitian ini

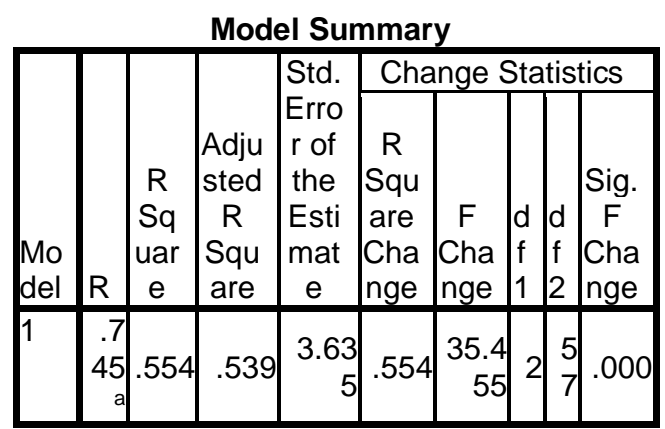

a. Predictors: (Constant), Lingkungan Kerja (X2), Kompensasi (X1)

Sumber : Hasil Output SPSS 16.0

seperti motivasi kerja, gaya kepemimpinan, disiplin kerja, dan lain-lain.

4. Uji Signifikansi

a. Uji t ( Parsial)

Uji $\mathrm{t}$ dilakukan untuk mengetahui pengaruh masing-masing atau secara parsial variabel independen (Kompensasi dan Lingkungan Kerja)terhadap vaiabel dependen (Kinerja Karywan). Sementara itu secara parsial pengaruh dari kedua variabel indpenden tersebut terhadap kinerja karyawan ditunjukan pada tabel berikut :

Tabel 4.12 Hasil Olahan Data Uji t (Parsial)

Coefficients $^{a}$

\begin{tabular}{|c|c|c|c|c|c|}
\hline \multirow[b]{2}{*}{ Model } & \multicolumn{2}{|c|}{$\begin{array}{l}\text { Unstandard } \\
\text { ized } \\
\text { Coefficients }\end{array}$} & \begin{tabular}{|c} 
Standardi \\
zed \\
Coefficien \\
ts
\end{tabular} & & \\
\hline & B & \begin{tabular}{|c|} 
Std. \\
Erro \\
$r$ \\
\end{tabular} & Beta & $\mathrm{T}$ & g. \\
\hline \begin{tabular}{l|l}
1 & (Constan \\
t)
\end{tabular} & 9.919 & 3.807 & & $\begin{array}{r}2.60 \\
5\end{array}$ & \\
\hline $\begin{array}{l}\text { Kompen } \\
\text { sasi (X1) }\end{array}$ & .236 & .107 & .258 & $\begin{array}{r}2.19 \\
8\end{array}$ & \\
\hline $\begin{array}{l}\text { Lingkung } \\
\text { an Kerja } \\
\text { (X2) }\end{array}$ & .548 & .117 & & & \\
\hline
\end{tabular}


a. Dependent Variable: Kinerja Karyawan (Y)

Sumber : Hasil Output SPSS 16.0

Pengaruh dari masing-masing variabel kompensasi dan lingkungan kerja terhadap kinerja karyawan dapa dilihat dari arah tanda dan tingkat signifikansi (probabilitas).

Berdasarkan pengujian diperoleh $t_{\text {hitung }}$ sebesar 2,198 dan jika dibandingkan dengan $t_{\text {tabel }}$ sebesar 2,002 menunjukan $t_{\text {hitung }} 2,198>t_{\text {tabel }}$ 2,002. Hal ini berarti $\mathrm{H}_{\mathrm{o}}$ ditolak atau dengan kata lain terdapat pengaruh kompensasi terhadap kinerja karyawan secara signifikan. $\mathrm{H}_{\mathrm{a}}$ diterima atau dengan kata lain adanya hubungan anatara kompensasi terhadap kinerja karyawan.

Berdasarkan pengujian diperoleh thitung sebesar 4,684 dan jika dibandingkan dengan $t_{\text {tabel }}$ sebesar 2,002 menunjukan $t_{\text {hitung }} 4,684>t_{\text {tabel }}$ 2,002. Hal ini berarti $\mathrm{H}_{\mathrm{o}}$ ditolak atau dengan kata lain terdapat pengaruh lingkungan kerja terhadap kinerja karyawan secara signifikan. $\mathrm{H}_{\mathrm{a}}$ diterima atau dengan kata lain adanya hubungan antara lingkungan kerja terhadap kinerja karyawan.

b. Uji F (Simultan)

Uji $F$ pada dasarnya menunjukan apakah semua variabel independen yang dimasukan dalam model mempunyai pengaruh secara bersamasama terhadap variabel dependennya. Hasil perhitungan uji $\mathrm{F}$ dapat dilihat pada tabel berikut:

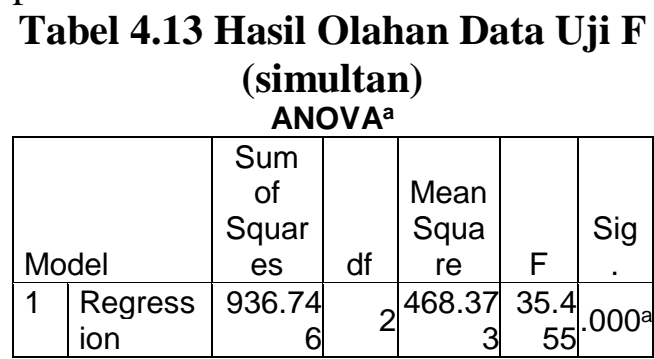

\begin{tabular}{|l|l|r|r|r|l|l|}
\hline \multirow{2}{*}{ Residual } & 752.98 & 57 & 13.210 & & \\
\cline { 2 - 6 } & 7 & & & \\
\hline
\end{tabular}

a. predictors: (constant), Lingkungan Kerja (X2), Kompensasi (X1)

b. Dependent Variable: Kinerja Karyawan (Y)

Sumber : Hasil Output SPSS 16.0,2018

Untuk variabel kompensasi $\left(\mathrm{X}_{1}\right)$ dan lingkungan kerja $\left(\mathrm{X}_{2}\right)$ secara bersama-sama 0,000. Karena nilai sig lebih kecil daripada $\alpha$ atau $0,000<$ 0,05 dan dari hasil uji $F_{\text {hitung }}(35,445)>$ $\mathrm{F}_{\text {tabel }}$ 3,16 maka $\mathrm{H}_{\mathrm{o}}$ ditolak. Jadi dapat disimpulkan bahwa kompensasi dan lingkungan kerja secara simultan berpengaruh signifikan terhadap kinerja karyawan PT. Indo TekhnoPlus.

\section{PENUTUP}

\section{A. Kesimpulan}

Berdasarkan hasil analisis data yang diperoleh dari kuisioner yang disebarkan penulis memberikan beberapa kesimpulan yang dapat dirumuskan sebagai berikut:

1. Pelaksanaan kompensasi pada PT. Indo TekhnoPlus sudah baik sesuai dengan hasil kuesioner SS $+\mathrm{S}$ $=18,3 \%+60,7 \%=79 \%$ pernyataan dengan nilai tertinggi ada pada pernyataan nomer 1 yaitu mendapatkan gaji atas pekerjaan setiap bulan secara tepat waktu sehingga perlu dipertahankan.

2. Pelaksanaan lingkungan kerja PT. Indo TekhnoPlus sudah baik sesuai dengan hasil kuesioner $\mathrm{SS}+\mathrm{S}=$ $30,5 \%+57,7 \%=88,2 \%$ pernyataan dengan nilai tertinggi ada pada pernyataan nomer 5 yaitu sudah merasa aman saat berada ditempat kerja. 
3. Pelaksanaan kinerja karyawan yang dilakukan oleh karyawan PT. Indo TekhnoPlussudah baik sesuai dengan hasil kuesioner $\mathrm{SS}+\mathrm{S}=$ $27,3+66,5 \%=93,8 \%$ pernyataan dengan nilai tertinggi ada pada pernyataan nomor 6 yaitu dalam menyelesaikan pekerjaan saya selalu berinsiatif tanpa menunggu perintah dari pemimpin sehingga perlu dipertahankan.

4. Persamaan regresi linear berganda $\mathrm{Y}=9,919+0,236 \mathrm{X}_{1}+0,548 \mathrm{X}_{2}$ hal ini membuktikan bahwa kompensasi terhadap kinerja karyawan berpengaruh positif dan lingkungan kerja terhadap kinerja karyawan berpengaruh positif.

Nilai korelasi berganda diperoleh angka $\mathrm{R}$ sebesar 0,745 hal ini berarti terdapat pengaruh yang kuat antara kompensasi, lingkungan kerja terhadap kinerja karyawan.

Dilihat dari hasil koefisien penentu hal ini berarti variabel independen yaitu kompensasidan lingkungan kerja mampu menjelaskan bahwa variabel dependennya yaitu kinerja karyawan sebesar $53,9 \%$ sedangkan sisanya $46,1 \%$ dijelaskan oleh faktor-faktor lain yang tidak dicantumkan dalam penelitian ini seperti motivasi kerja, gaya kepemimpinan, disiplin kerja dll.

Uji signifikansi secara simultan $F_{\text {hitung }}(35,445)>F_{\text {tabel }}$ 3,16 maka $\mathrm{H}_{\mathrm{o}}$ ditolak. Jadi dapat disimpulkan bahwa kompensasi dan lingkungan kerja secara simultan berpengaruh signifikan terhadap kinerja karyawan PT. Indo TekhnoPlus.

\section{B. Saran}

Berdasarkan hasil analisis dan perhitungan dari sebelumnya maka penulis memberikan beberapa saran yang diharapkan dapat menjadikan masukan untuk PT. Indo TekhnoPlus agar kedepannya lebih baik lagi.

1. Pelaksanaan kompensasi pada PT. Indo TekhnoPlus dengan pernyataan nilai terendah ada pada pernyataan nomor 7 yaitu Puas dengan jaminan sosial tenaga kerja yang diberikan perusahaan disarankan perusahaan lebih meningkatkan jaminan sosial yang diberikan terhadap karyawan agar karyawan merasa lebih terlindungi lagi dalam bekerja sehingga diharapkan dapat meningkatkan kinerjanya dalam bekerja.

2. Pelaksanaan disiplin kerja pada PT. Indo TekhnoPlus dengan pernyataan nilai terendah ada pada pernyataan nomor 10 yaitu polusi kurang baik dapat memperlambat dalam menyelesaikan pekerjaan disarankan agar perusahaan memberikan perhatian lebih terhadap sirkulasi udara di kantor sehingga karyawan dapat bekerja secara lebih maksimal.

3. Pelaksanaan kinerja karyawan pada PT. Bank BCA Syariah Kantor Cabang Utama Jatinegara Jakarta Timur dengan pernyataan nilai terendah ada pada pernyataan nomor 1 yaitu selalu berusaha menyelesaikan pekerjaan secara benar dan sesuai waktu 
yang di tetapkan disarankan agar mendapat perhatian khusus sehingga dapat memberikan hasil yang maksimal bagi perusahaan.

4. Berdasarkan hasil penelitian menunjukkan bahwa terdapat pengaruh yang signifikan sehingga disarankan kepada perusahaan untuk meningkatkan kinerja karyawan dapat melalui peningkatan kompensasi dan lingkungan kerja.

\section{DAFTAR PUSTAKA}

Yani, M. " Manajemen Sumber Daya Manusia“. Jakarta: Mitra Wacana Media, 2012.

Sunyoto, Danang. “ Manajemen sumber Daya Manusia “, Jakarta: PT Buku Seru, 2012.

Sedarmayanti. “ Manajemen Sumber Daya Manusia Reformasi Birokasi dan Manajemen Pegawai Negeri Sipil", cetakan kelima, Bandung: PT Refka Aditama, 2011.

S.P, Hasibuan, Malayu. " Manajemen Sumber Daya Manusia ", Jakarta : Bumi Aksara, 2010.

\section{Sugiyono. "Memahami Penelitian Kualitatif", Bandung: \\ ALFABETA, 2012.}

Rivai, Veithzal dan Sagala, Ella Jauvani. " Manajemen Sumber Daya Manusia untuk perusahaan dari teori ke praktik“, Jakarta: PT Raja Grafindo,2011.

Kamsir. "Manajemen Sumber Daya Manusia (teori dan praktik) "
Depok: PT. Rajagrafindo Persada, 2016.

Silalahi, Ulber. "Asas-asas Manejemen". Bandung: Refika Aditama, 2011.

Zainun, Buchari. "Pendidikan dan Pelatihan Sumber Daya Manusia". Jakarta: IPWI, 2010.

Dessler, Garry. "Manajemen Sumber Daya Manusia”. Jakarta: Salemba Empat, 2015.

Mangkunegara, A.A Anwar Prabu, "Manajemen Sumber Daya Manusia

Perusahaan ", Remaja Rosdakarya, Bandung, 2008

Moeheriono. "Pengukuran Kinerja Berbasis Kompetensi”. Bogor: penerbit Ghalia Indonesia, 2010.

Jamil, Suprihatiningrum. " strategi pembelajaran", Yogyakarta: ARuzz Media, 2012

Edy, Sutrisno. " Manajemen Sumber Daya Manusia", Cetakan Pertama, Jakarta: Penerbit Kencana, 2010.

Sastrohadiwiryo. " Manajemen Tenaga Kerja Indonesia Pendekatan Adminiatrasi dan Operasional", Jakarta: Bumi Aksara, 2013.

Ardana. “ Manajemen Sumber Daya Manusia”, Yogyakarta: Graha Ilmu, 2012.

S.P, Hasibuan, Malayu. "Manajamen Sumber Daya Manusia", 
Jakarta: PT. Bumi Aksara, 2013.

Alex, S. M. “ Untung Besar Budi Daya Aneka Jamur". Yogyakarta: Pustaka Baru Press. 2011.

Sugiyono. " Metodelogi Penelitian Kuantitatif, Kualitatif Dan
R\&D”.

Bandung:

Sugiyono. " Metodelogi Penelitian Kuantitatif, Kualitatif Dan R\&D".

Bandung:

ALFABETA, 2010 